\title{
The EU: Big on Big Things and Smaller on Smaller Things ${ }^{1}$
}

\author{
Bilge Filiz \\ Phd Cand, Ankara University, Turkey \\ Visiting Researcher between March 2017-March 2018 at the University of Alcalá, Spain (Scholar of TUBITAK- The \\ Scientific and Technological Research Council of Turkey)
}

\begin{abstract}
Welfare regime is composed of the social and economic policies that are adopted to protect and promote the economic and social well-being of its citizens. While neoliberal principles extend through globalization, welfare regimes have been suffering from this process since policies are developed with the emphasis on individual empowerment rather than collectively shared welfare. While spending a great deal of efforts not to lose its competitiveness, the European Union tries to create an alternative for the structure of its social policies. However, this attempt remains highly vulnerable due to the impact of capitalist economic system on development of EU social policy/model since the beginning of the EU integration process. This article analyzes the roots of underdeveloped social policy in EU history at three stages: explanation of underdevelopment of social Europe from several theoretical paradigms; examination of deep-rooted problems of European social policy within the dynamics of European integration; elaboration of EU modernization process; and clarification of this deficiency with the example of European Social Model deemed as a politically constructed project.
\end{abstract}

Keywords: Social policy, Welfare regime, European integration, Modernization, Empowerment of Individuals, Activation.

\section{Introduction}

Within the severe capitalism, welfare state has evolved into a mix of social and economic policies in order to tame pure market capitalism and to decrease or lighten its possible inhuman effects on the 'social citizens' - if still exist any in today's capitalist world. In the same direction, Jacques Delors introduced for EU member states the 'European Social Model' in the mid-1980s as an alternative to the American form of the severe capitalism (Jepsen, Pascual, 2005). The EU has been comparatively seen as a unique example of political and economic body that manages its economic growth by increasing social justice and equity in today's competitive world. However, even if $\mathrm{EU}$, as a union, struggles for creating an alternative and for maintaining social justice in its societies, the ideology behind capitalist economic system has a great impact on development of EU social policy/model. This article tries to respond the question of 'How the roots of underdeveloped social policy at EU level can be explained?' The analysis goes through three stages. First of all, how different scholars reflecting different theoretical paradigms explain the reasons of underdevelopment of social Europe is briefly discussed. In this part, arguments are built on multidimentional explanations of David Bailey. Deep-rooted problems of European social policy are scrutinized at the second stage by examining in detail the dynamics of European integration through its judicial power: European Court of Justice (ECJ). The leading explanations of Richard Münch shed a light on this part of research to understand the formation of market based citizen point of view at European level. Finally, European Social Model, assumed as a politically constructed project, is reviewed as an example to identify how the logic behind development of social Europe: the mechanisms of activation and flexibility and therefore instruments of employability and flexicurity are settled in the EU discourse.

During the recent times of crisis in the EU, the underdeveloped social policy is being reflected in several speeches of EU leaders. Former President of EU Commission Barroso, in his State of the Union address, on 11th September 2013 at European Parliament, questioned:

\footnotetext{
1 One of the most important case supporting this argument is: Case C-438/05 of European Court of Justice: International Transport Workers' Federation and Finnish Seamen's Union v Viking Line ABP and OÜ Viking Line Eesti, judgment of 11 December 2007.
} 
"'Do we want to improve Europe, or give it up? My answer is clear. Engage! If you don't like Europe as it is. Improve it! As any human endeavor, the EU is not perfect. Controversies about the division of labor between the national and European levels will never be conclusively ended. Not everything needs a solution at European level. Europe must focus on where it can add most value. It does not have to meddle where this is not the case. The EU needs to be big on big things and smaller on smaller things' (Barrasso, 2013, September 11).

This part of the speech of former President of EU Commission may have several implications for different EU scholars. But from the social policy perspective, it reflects several indications of historically constructed obstacles to Social Europe. The basic question here is whether the values of social solidarity and collectively shared welfare are bigger or smaller things.

'Solidarity' comes with the social market capitalism of Europe and is widely considered as an essential aspect of European integration (Gerrits, n.d.). However, even if this understanding of solidarity highlighting social market is expected to sustain collectively shared welfare, it is underlined several times in leaders' speech of EU as a cement for economic union. The subordination of socialness to the primacy of economics is becoming more obvious. For instance, President of EU Commission, Jean Claude Junker, in his annual State of the European Union Speech on $14^{\text {th }}$ September 2016 stated:

"Solidarity is the glue that keeps our Union together. The word solidarity appears 16 times in the Treaties which all our Member States agreed and ratified...Our European budget is living proof of financial solidarity...The euro is an expression of solidarity. Our development policy is a strong external sign of solidarity... We often show solidarity most readily when faced with emergencies."

\section{Explaining the Obstacles to Social Europe}

The guiding principle of welfare state in European countries has been maintaining status security (ex. protection of workers during the period of illness, unemployment or retirement) (Offe, C. 2003). After 1980s, it gradually forfeits even this main guiding principle during the adaptation of pure market capitalism in order not to lose its competitive power at EU level. For this reason, some scholars describe the social policy of the EU as an empty shell (Falkner in Bailey, 2008) and a constitutional asymmetry between policies promoting market efficiencies -which prevail- and policies promoting social protection and equality (Scharpf in Bailey, 2008). On the process of understanding main obstacles to Social Europe, David Bailey (2008) provides a clear picture of how several scholars reflecting different theoretical paradigms explain the reasons of underdevelopment of social Europe. He combines the series of obstacles identified by several theoretical paradigms to explain this deficiency of EU. Seven different explanations of different paradigms are specified concerning the obstacles to Social Europe:

According to neo-functionalism, EU focuses on market integration in the historical development of European integration and thus social policies are put in the subordinated position. They also believe that economic integration can and will have a spillover effect on greater social policy integration (Jensen; Threlfall; Conant in Bailey, 2008).

The underdevelopment of European social policy is also explained by the ongoing divergence between national economic and/or political conditions within the various states (Scharpf; Goetschy; Mosher; Trubek in Bailey, 2008). With respect to this perspective, differences in national economies and political situations result in the adaptation of different welfare regimes, which obstructs the integrated social development at EU level.

The Open Method of Coordination (OMC) School, on the other hand, believes that national divergence is an obstacle but can be overcome through alternative 'softer' forms of cooperation such as OMC (Ferrera; Zeitlin in Bailey, 2008).

New institutionalism points out the impact of the highly complex institutional configuration of the European Union in understanding the limits of EU social policy (Geyer, 2010). The implementation requiring multiple and complex procedures in EU institutional structure complicates the involvement of several social actors into the process. On the other hand, similar to neo-functionalists, new institutionalists argue that EU's initial focus to economic matters creates a path dependence through market confirming rather than market-correcting policies and as social policy developments are seen as an intervention to the market, these policies are emerged in the agenda of EU as something to be avoided.

Critical democratic approach, similar to new institutionalists, blames the non-participatory nature of much of European level decision making (Warleigh in Bailey, 2008). As known, decisions are taken without sufficient contribution of social partners. Therefore, they do not reflect the interests of real partners being affected by the process. 
Identity based explanations focuses on the dominance of national identities while explaining the underdevelopment of Social Europe. According to them, as there is no European identity, civil society participation is low at European level and this makes social policy implementation at EU level impossible.

Marxist scholars explain the obstacle to Social Europe in terms of the dominance of capital over labor within European capitalism (Carchedi in Bailey, 2008). Therefore, according to them, the main intention of European integration is to limit market correction policies and to prevent any intervention in order to make the market more profitable. That's why social Europe is underdeveloped.

All these explanations illustrate one dimension of the social problem of Europe. David Bailey, thinking in the same way, combines all and constructs three levels structure: EU wide social stratum, political stratum and institutional stratum with the method of critical realism which asserts that social realities are created by social structures and relations. Assuming that EU-wide social relations existing in a deeper stratum than political relations stratum which abide in greater breadth than institutional stratum, economic interest based EU wide social relations generated political relations and then institutional relations in the same direction: prioritizing economic gain. In fact, the assertion of Bailey suggests that the obstacle of Social Europe is derived from the institutional obstacles to EU level social policy making that has been formulated through political relations of member states and capitalist relations of production of its societies.

In order to scrutinize this point of view, the second part of this article analyzes the main driving force of European integration in its institutionalization process and its impact on development of European social policy.

\section{Empowerment of Individuals through EU law}

The main driving force of European integration is to design European single market without interventions and not to protect but to empower individuals through several mechanisms. Richard Münch (2008) indicates how European law has emerged in close connection with economic needs of market integration and how European Court of Justice's jurisdiction has contributed to the change of solidarity and construction of European society basing on individual empowerment and activation.

Münch (2008) argues that increasing specialization and cross-border labor division result in intensive international trade and thus economic integration, but it is believed that market transactions cannot automatically result in the transformation of solidarity and legal order because solidarity change brings great power struggle and market transactions cannot have spillover effect over solidarity change. For this reason, transnational solidarity is created by transnational elites through construction of transnational institutions promoting superimposition of transnational solidarity on national societies by creation of European law. The European law is designed to advance individual autonomy in line with the model of market exchange and save the individuals from traditionally established national limits.

While national law reflects the cultural traditions, European law excludes itself from national law and includes rules to strengthen the individuals. As a result, uniform cultures are polarized and transnational ties are built between individuals and this explains how European society and new type of solidarity are emerged. This new type of solidarity emphasizes on the values of interdependence in purely and simply economic terms.

During this transformation, in order to eliminate any possible resistance and conflict between national and transnational forces, Münch (2008) explains clearly that the process has been legitimized in four steps.

The need of institutionalization of European judicial power in order for the elites to proceed with their transnational project.

The requirement of establishing a leading idea and concept of control in order for the transformation of solidarity to be acceptable by national and transnational forces. The constructed leading idea is the spread of values free movement and nondiscrimination.

Establishing a dominant European legal community and turning politics into juridical technique.

Turning functional adjustment into constructing a legitimate order

Concerning the institutionalization of European judicial power, as known, the preliminary position of European law strengthens gradually. Moreover, ECJ's decisions on direct effect and supremacy of law provide a guarantee for the legitimate power of European legal order. It also plays a crucial role on legal harmonization of national laws. Therefore, 
basing on these powerful tools, ECJ shifts juridical power from national to European level and creates legal framework for market integration by eliminating any obstacle in front of the open competition, specialization and European labor division.

At the second step, free movement and non- discrimination principles fostered by European law are able to replace the traditional ideas of national welfare because these concepts shift the power in favor of competitive companies and single individuals if they seek the advantages of European market without national barriers. Both free movement and nondiscrimination are designed to bring economic self-sufficiency for individuals (In fact, free movement was seen simply as economic activity rather than citizenship right before 2000s) (Münch, 2008). These principles are applied frankly to remove trade barriers, but are fostered as basic principles of justice. Therefore, they are perceived as legitimate principles by competitive companies and individuals that promote competition on European level and provide legitimate framework for them to increase European division of labor.

At the third step, it is explained that aquis comunautaire is created by European elite of academics, judges and lawyers and they provide a legitimate power for ECJ which is also given a big role to overcome the lack of legal harmonization and remove the obstacles to integration project. Therefore, it successfully converts the matters into technical terms and enlarges its impact area. After this process, national resistance has been weakened and is seen as search for interests. However, legal reasoning has turned the politics into juridical technique and is seen as more logical on promoting European single market. Consequently, ECJ has been able to construct autonomous European legal framework that national governments cannot reach and affect this framework. Moreover, functional differentiation of EU law becomes a power struggle with national forces for the formation of legal order. This is the basis of transforming national legal traditions into transnational ones.

At the final and the most important step, it is noted by Richard Münch (2008) that European legal order is designed with the emphasis on individual achievement, equality of opportunity and individual empowerment rather than status security, equality of results and collective and shared welfare. The European law constructs a society from market citizen point of view and, therefore, ECJ takes into account empowered, knowledgeable individuals and disregards the others that do not fill the minimum standards for the competitive economy. Moreover, protecting these people's rights below the standards is not the aim of the European law as the protection logic is against the competitive single market. ${ }^{1}$

The individuals are expected to use their liberties on the market to realize their own ideas, values and interests. This is the message given by European law in its jurisdiction. Therefore, it is possible to conclude that European law strengthens the individuals against their community of origin and it institutionalizes individualism because main point promoted by European legal order is self-realization of individual. It is appropriate for market citizen of liberalism rather than political citizen of republicanism or social citizen of social democratic welfare state (Münch, 2008). Therefore, this structural change of solidarity excludes the values of equality of living standards and protection of the individual by the state. Moreover, greater inequality is the inevitable consequence of this structural change. Therefore, construction of this order is costly and highly debated process but ECJ jurisdiction has been made a great contribution to set this transformation.

To sum up, ECJ plays important role on European integration and construction of European society on the basis of empowerment of individuals. It has been successfully institutionalized by transnational elite, has gained legitimacy through spread of the values of free movement and non-discrimination and it can be easily considered as capable to shift solidarity from national to European level by converting the national citizens to market citizens or market actors.

Therefore, according to Münch, both European institutions and European law are designed to adapt the European society to new structure of market economy by trying to create a European identity from market citizen point of view. It is not then surprising that current attempts of developing social Europe do not contain principles of equal distribution of wealth and public responsibility for those incapable to obtain minimal provisions for a decent life. Moreover, it is not surprising that in 2013, former president of EU Commission underestimates the social dimension of European Union integration project by declaring that 'the EU needs to be big on big things and smaller on smaller things'

\footnotetext{
1 See social pillar of Europe 2020 Strategy targets:

https://ec.europa.eu/info/strategy/european-semester/framework/europe-2020-strategy_en\#featuresofthetargets
} 
The EU, from the beginning of its integration process, has removed itself from pursuing such a welfare regime that the political and economic organization take an active role to protect and promote the economic and social well-being of its citizens. This removal can be observed in the process of construction of European Social Model.

\section{Modernization of EU and European Social Model (ESM) as a Political Project}

As indicated in the initial part of the article, in the capital world, welfare regime has evolved into a mix of social and economic policies in order to tame pure market capitalism and to decrease or lighten its possible inhuman effects on the 'social citizens'. The guiding principle of welfare state of European countries was to secure and to protect individuals (Offe, 2003). This logic of protection means providing social benefits for the individuals against market contingencies through social security programmes. At this point, Offe (2003) explains this structure of security by resembling the concept of welfare state to the building that has three floors and a roof.

According to him, the ground floor contains provisions regulating access to labor markets and to jobs and issues of health and safety at work. The second floor is the scene of provisions pertaining to the social security of the wage worker outside of work and in the absence of income out of currently earned wages (transfer payments or day care services). On the third floor, the institutional devices are intended to deal with the decline of workers' capacity to defend their income (against inflation or increases in productivity). Finally, the roof of building is a set of policies designed to protect the various statusconferring and security arrangements explained in other floors. (Offe, 2003).

The state, as a reason for being, has an important role on building this structure, namely, on providing this type of security to its citizens in order to maintain the social justice in the society. This role cannot be sacrificed under the concept of selfrealization of the individual. It can be logically questioned why state, as a political organization, exists if all individuals are considered as actors of market and market is able to regulate itself. Similarly, the legitimacy of European Union, as a supranational body, is questioned while it is transforming itself a regime of stabilization of member states to regime of modernization of the Union itself. The former was mainly based on supportive social regulation while the latter is based more on promoting transformation of social models under the guideline of neoliberal flexibilisation and deregulation (Hermann, Hofbauer, 2007).

European Commission declares that such a modernization is becoming urgent due to the challenges on financing social protection systems and responding to the needs of an older population in terms of working conditions, health, and quality of life (Jepsen, Pascual, 2005). This modernization has emerged in the EU in order to respond the changes as follows:

'Economic integration has diminished the capacity of member states to use traditional economic policy instruments and thus has complicated the achievement of self-defined social policies;

Demographic and societal changes (the ageing population and entry of women to labor market) has changed the balances in social protection systems in terms of health and pension spending and long-term care servicing (which was carried out by women);

Changes in European/world production model that means long-term planning is impossible and risks are unpredictable.' (Jepsen, Pascual, 2005).

With the aim of legitimizing minimal social policies, the EU argues - in the consideration of these changes - that promotion of the flexibility and concentration on promotion of the management of risks by individuals - rather than protecting against them - are inevitable. ${ }^{1}$ Therefore, EU raises the ideas of activation, flexicurity, partnership in order to convert national social policies into an instrument for optimizing the adjustment of social protection systems to market forces at transnational level (Jepsen, Pascual, 2005).

Fostering such a modernization and making the individuals active at transnational level, the formation of European Social Model is seen as an example on how European identity is being promoted based on shared social problems and solutions but not on values. The Commission's 1994 White Paper on social policy (COM (94) 333) described a 'European social model' in terms of principles that include democracy and individual rights, free collective bargaining, the market

\footnotetext{
1 Thailand Food Innopolis is a global food innovation hub focusing on research, development and innovation for food industry. It is fully equipped with qualified human resources and facilities to support food producers of all scales, be it local, regional, or global. We provide a platform to strengthen your business and also to innovate your food industry.
} 
economy, equal opportunities for all, and social protection and solidarity (Eurofound, 5 May 2011). However, Maria Jepsen and Amparo Serrano Pascual argue that ESM can be regarded as a political construction in the framework of a demand for legitimacy generated by EU project while facing new challenges (Jepsen, Pascual, 2005).

The emergent socio-economic problems and the methods to tackle them bear ESM as a means of achieving the objective of constructing self-styled European social policy identity. The European institutions have successfully europeanized the rising challenges and put them into the agenda of all its member states. The concepts such as workfare is relabeled as activation, flexibility as flexicurity, globalization as knowledge-based society and corporate governance as social corporate responsibility while the reality/philosophy behind these concept remain the same - without no value addition (Jepsen, Pascual, 2005). In this process, European institutions pairs up the common challenges and creates common tools to solve these problems instead of spreading common values. For instance, they provide so called instruments (work first policies, employability, flexicurity, investing in people) that will allow individuals to find ways of adapting to changing economic and social conditions (Jepsen, Pascual, 2005). However, these activation policies that follows a 'workfare' approach will aggravate the problems, not reduce them (Seikel, 2017).

Therefore, EU institutions - similar to their previous attempts - aim to bring together the individuals - rather than member states - on responding new economic changes and solving the social problems. European Social Model is just one of the examples of these attempts. Then, similar to ECJ case law, this formation can be considered as a political project that fosters a European identity based on principles of market capitalism.

\section{Conclusion}

The EU plays a significant role in transforming the solidarity of its citizens to the transnational level while subordinating social rights to economic rights. For the sake of sustaining its competitiveness, social issues are being considered as less important when compared to issues that can bring economic benefits. The EU, as a supranational body, builds and implements political and institutional projects to achieve these objectives. In these projects such as constitution of European case law or even European Social Model, social dimension of the Union has been regarded as a tool in order to guarantee well-functioning of the economic integration. The ones who evaluate the EU as a unique example of political and economic body that manages its economic growth by increasing social justice and equity in today's competitive world should be aware of the fact that this uniqueness comes from the culture created after a political, economic and social struggle of the societies, mainly working classes, in some European member states.

This struggle brought and guaranteed several social rights in European continent. The European Union, as a supranational body, has a weakening effect to implementation of social welfare mechanism in these member states. The Union promotes the flexibilisation of labor policies, narrowing social protection coverage, privatization of public services with the concern of efficiency and competitiveness. Unlike many other policies, social policies at EU level are nonbinding policies that are implemented in order to solve the problems emerged after neoliberal integration process such as unemployment, poverty and social exclusion.

Therefore, before coming to the efficiency of European social policy, it is more logical to ask: Is there a social policy at EU level or what makes policies social for European society now?

\section{Acknowledgments}

I would like to express my special thanks and gratitude to my father, Prof .Dr. Hüseyin Filiz, as well as my esteemed colleague, Aqil Zahirpour, for their valuable comments on this article. 


\section{References}

[1] Bailey, D.J (2008). Explaining the underdevelopment of 'Social Europe': a critical realization. Journal of European Social Policy, vol.18 (3): 232-245. doi: 10.1177/0958928708091057.

[2] Barrasso (2013, September 11). Make the case for Europe. Daily News of 2013.09.11 European Commission. Retrieved from http://europa.eu/rapid/midday-express-11-09-2013.htm

[3] Clift, B. (2007). Europeanizing Social Models? Journal of European Integration, vol.29, no.2:249-254. doi: 10.1080/07036330701252607.

[4] European Social Model. Eurofound, 5 May 2011. Web 24 December 2013 Retrieved from: http://www.eurofound.europa.eu/areas/industrialrelations/dictionary/definitions/europeansocialmodel.htm

[5] Geyer, R. (2010). The State of European Union Social Policy. Policy Studies, 21:3, 245-261.

[6] Gerrits, A.W.M. (n.d.) Solidarity and the European Union: From the Welfare State to the Euro Crisis. International Studies, European Union Studies, Leiden University. Retrieved from: http://media.leidenuniv.n//legacy/solidarityand-the-european-union.pdf

[7] Hermann,C. \& Hofbauer (2007). The European social model: Between competitive modernisation and neoliberal resistance. Capital\& Class 31:125-139.

[8] Jepsen, M. \& Pascual, S.A. (2005). The European Social Model: an exercise in desconstruction. Journal of European Social Policy, 15:231. doi: 10.1177/0958928705054087.

[9] Junker (2016, September 14). State of the Union Address 2016: Towards a better Europe- a Europe that protects, empowers and defends. European Commission- Speech- 11409/2016.Press Release Database Retrieved from: http://europa.eu/rapid/press-release_SPEECH-16-3043_en.htm

[10] Münch, R. (2008). Constructing a European Society by Jurisdiction. European Law Journal, vol.14, no.5: 519541.

[11] Offe, C. (2003). The European Model of Social Capitalism: Can it survive European Integration?. Journal of Political Philosophy, vol.11, n.4: 437-469.

[12] Seikel, D. (2017, September 1). Activation into In-Work Poverty? Social Europe. Retrieved from: https://www.socialeurope.eu/activation-work-poverty

\section{FOOTNOTES:}

1 Barrasso (2013, September 11). Make the case for Europe. Daily News of 2013.09.11 European Commission11/09/2013. Retrieved from http://europa.eu/rapid/midday-express-11-09-2013.htm

2 One of the most important case supporting this argument is: Case C-438/05 of European Court of Justice: International Transport Workers' Federation and Finnish Seamen's Union v Viking Line ABP and OÜ Viking Line Eesti, judgment of 11 December 2007.

3 See social pillar of Europe 2020 Strategy targets: https:/lec.europa.eu/info/strategy/europeansemester/framework/europe-2020-strategy_en\#featuresofthetargets 